\section{ASSESSMENT AND OUTLOOK}

$\mathbf{F}$ or almost three years now, the publication of our journal has been coordinated from Cachan through our subsidiary, RILEM Publications S.A.R.L.

Over this same period, the journal's editorial policy has been closely overseen by the Board of Editors; this body's members are elected to three-year terms by our Association's General Council, which holds its annual general assembly in September.

In order to strengthen our effort to disseminate the results of work being carried out by our Technical Committees, we have recently begun publishing RILEM conference and workshop proceedings; our upcoming plans also call for publishing the technical reports produced by the Technical Committees.

At the time of RILEM's annual week-long assembly, held September 21-25 in Australia this year and organized by our Honorary President, Dr. David Ho of the CSIRO, a new journal whose production is slated to begin in 1999 by our publishing subsidiary was also presented to attendees.

The project leading to this upcoming periodical, to be entitled Concrete Science and Engineering, was forwarded by Surendra Shah, Francis Young and Hans-Wolf Reinhardt.

This illustrious group of well-renowned scientists requires no introduction to you all. They participated up until 1998 in the $A C B M$ Journal published by Elsevier, which as of 1999 will be merged with the Cement and Concrete Research periodical.

In order to avert any potential misunderstanding, it is essential to highlight herein that Concrete Science and Engineering will in no way replace the $A C B M$ Joumal, which remains the exclusive property of the Elsevier Group. Along the same lines, Concrete Science and Engineering is not to replace Materials and Structures, which is, and will continue to be, the only scientific journal devoted to disseminating the results of the RILEM Technical Committees' working sessions. Furthermore, these two journals will not be competing with one another, as the fields each covers will not lead to any kind of overlapping. The two journals' respective Boards of Editors, working in close cooperation, will both have the opportunity to provide further details on this matter in one of their upcoming issues.

Concerning our Materials and Structures Joumal, a final piece of news, which our readers shouldn't have to wait until the end of the year to discover, is that in 1999, Volume 32 of the journal will comprise 80 inside pages, instead of the current 72 . This change reflects the significant increase in the number of quality articles submitted to our journal over the past twelve months.

In conclusion to this outlook and discussion of upcoming projects, I would in particular like to express my gratitude to the members of our journal's Scientific Committee for the tremendous work they've accomplished with diligence, care and professionalism.

Michel Brusin Secretary General, RILEM

\section{BILAN ET PERSPECTIVES}

D epuis près de trois ans, la production de notre journal est coordonnée depuis Cachan, par l'intermédiaire de notre filiale RILEM Publications S.A.R.L.

Dans le même temps, notre politique éditoriale est l'objet d'un suivi attentif par notre comité de rédaction, dont les membres sont élus pour trois ans par le Conseil Général de notre Association, réuni en assemblée générale annuelle au mois de septembre.

Pour renforcer notre action de diffusion des travaux de nos Commissions Techniques, nous avons récemment commencé à éditer les actes des conférences et ateliers RILEM, et bientôt également les rapports techniques produits par les Commissions Techniques de la RILEM.

À l'occasion de la semaine annuelle de la RILEM en Australie, du 21 au 25 septembre 1998, organisée par notre Président d'honneur, Dr David Ho du CSIRO, il a été en outre présenté un nouveau journal produit en 1999 par notre filiale d'édition.

Ce futur périodique, Concrete Science and Engineering, est une création dont le projet nous a été soumis par Surendra Shah, Francis Young et Hans-Wolf Reinhardt.

Ces scientifiques de renom n'ont pas besoin d'être présentés. Ils ont collaboré jusqu'en 1998 à l'ACBM Journal édité par Elsevier, journal qui à partir de 1999, sera fusionné avec le périodique Cement and Concrete Research.

Afin d'éviter tout malentendu, il importe de préciser que Concrete Science and Engineering ne remplace en aucune façon l'ACBM Journal, qui est la propriété $d u$ groupe Elsevier. De même, Concrete Science and Engineering ne remplacera pas Materials and Structures, qui est, et demeure, le seul journal scientifique diffusant les travaux émanant des Commissions Techniques de la RILEM. De plus, ces deux joumaux ne seront pas amenés à se faire concurrence, les domaines respectifs couverts ne devant pas donner lieu à des recouvrements. Les comités de rédaction de chacun des deux journaux, qui agissent en étroite coopération, auront l'occasion de revenir sur ce sujet dans l'un des prochains numéros de chaque revue.

Enfin, en ce qui concerne notre journal Matériaux et Constructions, et sans attendre la fin de l'année, il n'est pas inutile d'informer nos lecteurs que le volume 32 passera en 1999 de 72 à 80 pages intérieures, pour tenir compte de l'accroissement sensible du nombre d'articles de qualité soumis à notre journal au cours des douze derniers mois.

À l'issue de ce bilan et des projets de développement, il m'est particulièrement agréable de remercier le comité scientifique de notre journal pour le travail remarquable accompli avec soin, rigueur et exigence.

\section{Michel Brusin Secrétaire Général de la RILEM}

